\title{
Low expression of ORF4, a dominant negative variant of peroxisome proliferator-activated receptor $\gamma$, in colorectal adenocarcinoma
}

\author{
DELPHINE BOUANCHEAU ${ }^{1}$, ANNE JARRY ${ }^{1}$, STEPHANIE MOTTIER ${ }^{2}$, CLAIRE TOQUET $^{1}$, \\ DAMIEN MASSON $^{1}$, JEAN-FRANÇOIS MOSNIER $^{1},{\text { CHRISTIAN L. } \text { LABOISSE }^{1} \text { and MARC G. DENIS }}^{1,2}$ \\ ${ }^{1}$ INSERM U539, IFR26, Faculté de Médecine, 1 rue Gaston Veil, F-44035 Nantes; ${ }^{2}$ CNRS UMR 6061, \\ Université Rennes 1, IFR140, Faculté de Médecine, 2 avenue Pr Léon Bernard, F-35043 Rennes, France
}

Received January 8, 2007; Accepted March 9, 2007

\begin{abstract}
Peroxisome proliferator-activated receptor $\gamma$ (PPAR $\gamma$ ) agonists have been demonstrated to exert an inhibitory effect on cell growth, and to induce the cell differentiation and apoptosis of colorectal cancer cells. PPAR $\gamma$ was therefore proposed as a therapeutic target. Recently, a variant of PPAR $\gamma$ which functions as a dominant negative (ORF4) was described. Expression of this protein may prevent PPAR $\gamma$ ligand efficiency in colon cancer treatment. In an effort to evaluate the importance of this variant, we determined the expression level of PPAR $\gamma$ and that of the splicing variant ORF4 in a series of 28 human colon adenocarcinomas relative to paired normal mucosa by real-time PCR. PPAR $\gamma$ expression was found to be heterogeneous among tumors. ORF4 was also expressed, but represented $<10 \%$ of the PPAR $\gamma$ transcripts. This low level was also found in several human colon cancer cell lines treated or not with a specific PPAR $\gamma$ ligand in preparations of isolated human colonic epithelial cells and in mouse colon. We conclude that ORF4 expression is a general phenomenon, and that its low level should not affect the efficiency of selective PPAR $\gamma$ modulators in colon cancer treatment.
\end{abstract}

\section{Introduction}

Peroxisome proliferator-activated receptor $\gamma(\operatorname{PPAR} \gamma)$ is a member of the nuclear receptor superfamily of ligandactivated transcriptional factors. Numerous studies have shown that PPAR $\gamma$ is expressed in a variety of malignant

Correspondence to: Dr Marc G. Denis, CNRS UMR 6061, Université Rennes 1, IFR140, Faculté de Médecine, 2 avenue Pr Léon Bernard, F-35043 Rennes, France

E-mail: marc.denis@univ-rennes1.fr

Key words: colon cancer, expression, peroxisome proliferatoractivated receptor $\gamma$, splicing variant, dominant negative tissues including prostate, breast, and colon. The implication of PPAR $\gamma$ in colorectal carcinogenesis is still debated. In fact, contrasting with the observation of an increase in the number and burden of naturally occurring intestinal tumors in $\mathrm{APC}^{\mathrm{Min}}$ mice fed with a diet containing a PPAR $\gamma$ agonist $(1,2)$, several in vitro and in vivo models suggest that PPAR $\gamma$ ligands have colonic anticancer activity. First, treatment of colorectal carcinoma cell lines with PPAR $\gamma$ ligands induces cell cycle blockade resulting in the inhibition of cell proliferation, stimulates cell differentiation and/or promotes cell death $(3,4)$. In vivo, thiazolidinediones, PPAR $\gamma$ agonists, decrease the development of tumors derived from colon cancer cells in xenograft models (5-8), suppress colon carcinogenesis induced by azoxymethane in mice (9) and are able to reduce the number of chemically-induced aberrant crypt foci, which are early precursor lesions of colon cancer $(10,11)$. Consistent with these findings, PPAR $\gamma$ heterozygous knockout mice $\left(\operatorname{PPAR} \gamma^{+/-}\right)$have an increased susceptibility to develop tumors, including colon tumors, after administration of a carcinogen (12). These data, together with the antiproliferative activity of PPAR $\gamma$ ligands observed in many human colorectal cell lines, suggest that these molecules may have promise as anticancer drugs. However, the expression of wild-type functional PPAR $\gamma$ in cancer cells is a prerequisite for a successful treatment with PPAR $\gamma$ agonists.

Mutations of PPAR $\gamma$ have been reported in a few colon cancers. Sarraf et al (13) examined 55 primary sporadic colorectal carcinoma samples for somatic mutations. Four somatic mutations were found that affect the function of PPAR $\gamma$. In contrast, Ikezoe et al (14) found no mutation in the 58 colorectal tumors examined. Finally, a previously unidentified monoallelic point mutation located in exon 6 at codon 422 (K422Q) was identified by Gupta et al (15) in colon cancer cell lines. However, we did not detect this alteration in a series of 170 colorectal tumors (16).

In conclusion, somatic mutations in the PPAR gene are exceedingly rare events in colon cancer cells and should not prevent PPAR $\gamma$ efficiency in the treatment of colon cancer patients.

Recently, Sabatino et al (17) identified a new PPAR transcript, referred to as ORF4, which harbors a readthrough 
in intron 4. The expected translated protein lacks the ligandbinding domain encoded by exons 5 and 6 . This protein does not transactivate a reporter gene. Moreover, the isoform is dominant negative versus PPAR $\gamma$. Furthermore, ORF4 has not only lost the capacity to restrain cell growth but has acquired the potential to stimulate it. They concluded that the ability to counteract PPAR $\gamma$ suggests that ORF4 plays a role in the pathogenesis of colorectal cancers.

In an effort to evaluate the significance of quantitative and qualitative alterations in the expression of PPAR $\gamma$ in colon cancer, we measured the expression of PPAR $\gamma$ and the dominant negative ORF4 in a series of 28 human colon tumors and paired normal mucosa by real-time PCR. We also analyzed several human colon cancer cell lines and preparations of isolated human colonic epithelial cells, and conclude that deregulation of PPAR $\gamma$ function in colon adenocarcinoma does not involve altered expression of its dominant negative ORF4.

\section{Materials and methods}

Tumor samples. Twenty-eight consecutive patients with primary colon adenocarcinoma treated at the Department of Surgery (Centre Hospitalier Universitaire of Nantes, France) were included in the study. There were 18 men and 10 women with a mean age of 72.4 years (median, 75; range, 59-83). The condition of the patients was assessed according to the system of staging the primary tumor, and regional lymph node and distant metastasis (TNM) as described in the AJCC Cancer Manual. The World Health Organization Classification of Tumors was used to determine histological classification. The 28 patients were classified into the TNM stages as follows: stage 1, 3 patients; stage 2, 16; stage 3, 6; and stage 4, 3 patients. Histologically, the tumors were divided into 12 well-differentiated, 14 moderately differentiated, and 2 poorly differentiated adenocarcinomas. Eighteen tumors originated in the right colon, 1 in the transverse colon, 4 in the left colon and 5 in the sigmoid colon. None of these patients underwent radiotherapy or chemotherapy before surgery. For these 28 patients, snap-frozen tumor samples and paired normal colonic tissue taken at a distance from the tumor $(10 \mathrm{~cm})$ were available, collected by the Biobank of Institut Regional du Cancer de Nantes Atlantique, according to the Guidelines of the French Ethics Committee for Research on Human Tissues.

Isolation of normal human colonic epithelial cells. Human colonic epithelial cells were isolated from histologically normal colon $(\mathrm{n}=3)$ and excised at a distance $(10 \mathrm{~cm})$ from the surgically resectioned colon cancer tumor using a nonenzymatic dissociation technique as described previously (18). Preparations of colonocytes were devoid of contamination by immune cells (18). Colonic epithelial cells were also isolated from the inflamed mucosa of the surgical resections from patients with active ulcerative colitis $(n=3)$.

Human colonic cancer cell lines. Several human colonic cancer cell lines were used. The differentiated clonal derivatives; HT29-Cl.16E of the HT29 cell line (19), Caco2 and T84 cells were grown on transwell filters (Corning-
Costar, Cambridge, MA). SW1116, SW620 and LS174T cells were grown on plastic. All these cell lines were cultured in DMEM (Invitrogen, Cergy Pontoise, France) supplemented with $10 \%$ fetal bovine serum (FBS, Invitrogen) and used at post-confluency (SW1116, SW620 and LS174T) or until full differentiation (HT29-Cl.16E, Caco2 and T84).

The PPAR $\gamma$ agonist GW7845 (20), generously provided by GlaxoSmithKline (Research Triangle Park, NC), was used at a final concentration of $5 \mu \mathrm{M}$. Cells were exposed to GW7845 or DMSO (0.05\% v/v) for $18 \mathrm{~h}$.

cDNA synthesis and real-time PCR. Total RNA was extracted from cells, tumor samples and paired normal colonic tissue using TRIzol ${ }^{\circledR}$ protocol (http://www.invitrogen.com/ content/sfs/manuals/15596026.pdf), and the Fast Prep cell disrupter (Q-Biogen, MP Biomedicals, Illkirch, France). cDNA was synthesized as previously detailed (21).

The amplification conditions of the different templates were optimized for the Rotorgene 3000 instrument (Corbett Research, BioLabo, Archamps, France). Primers were designed from the sequence of the human cDNAs using the GeneJockey software. They were selected for binding to separate exons to avoid false positive results arising from amplification of contaminating genomic DNA. We verified that all amplifications did not yield any product when reverse transcriptase was omitted in the cDNA synthesis reaction. The sequences of these primers are presented in Table I. PCR amplifications were performed using the LC480 SYBRGreen I Master mix (Roche Diagnostics, Meylan, France). The reaction mixture contained $10 \mu 1$ of the supplied $2 \mathrm{X}$ mix, $0.5 \mu \mathrm{l}$ of each primer (final concentration, $0.25 \mu \mathrm{M}$ each), and $9 \mu \mathrm{l}$ of the template (cDNA, diluted 1:20). The cycling conditions were as follows: denaturation for $5 \mathrm{~min}$ at $95^{\circ} \mathrm{C}$, amplification for 35 cycles with denaturation for $5 \mathrm{sec}$ at $95^{\circ} \mathrm{C}$, annealing for $5 \mathrm{sec}$ and extension for $5 \mathrm{sec}$ at $72^{\circ} \mathrm{C}$. To exclude primer-dimer artifacts, fluorescence was not measured at the end of the extension step, but a separate detection step was added $(10 \mathrm{sec})$ at a temperature above the melting point of the primer-dimers and below the melting point of the specific PCR product (Table I). After completion of the cycling process, samples were subjected to a temperature ramp from $63-99^{\circ} \mathrm{C}$, with continuous fluorescence monitoring for melting curve analysis. For each amplification, apart from the primer-dimers, a single narrow peak was obtained at the expected melting temperature, indicating specific amplification without significant byproducts. A standard curve was generated with serial dilutions of pooled cDNA samples. For comparison of the PPAR $\gamma$ and ORF4 expression level, the corresponding cDNAs were amplified, purified, and the concentrations were measured, allowing comparison of the levels of PPAR $\gamma$ and ORF4 transcripts for each sample. The reference curves were constructed by plotting the relative amounts of these dilutions vs the corresponding $\mathrm{Ct}$ (threshold cycle) values. The amount of transcripts was calculated from these standard curves using the RotorGene software. For each sample, the ratio between the relative amount of each specific transcript and $\beta$-actin was then calculated to compensate for variations in quantity or quality of starting mRNA as well as for differences in reverse transcriptase efficiency. Each amplification was performed in triplicate. 
Table I. Primers for real-time RT-PCR analysis.

\begin{tabular}{|c|c|c|c|c|}
\hline & Primer sequences $\left(5^{\prime}-3^{\prime}\right)$ & $\begin{array}{l}\text { Size of the } \\
\text { amplicon } \\
\text { (bp) }\end{array}$ & $\begin{array}{c}\text { Annealing } \\
\text { temperature } \\
\left({ }^{\circ} \mathrm{C}\right)\end{array}$ & $\begin{array}{c}\text { Acquisition } \\
\text { temperature } \\
\left({ }^{\circ} \mathrm{C}\right)\end{array}$ \\
\hline $\operatorname{PPAR} \gamma$ & $\begin{array}{l}\text { CAG TGG GGA TGT CTC ATA ATG C } \\
\text { ACC TCT TTG CTC TGC TCC T }\end{array}$ & 316 & 65 & 87 \\
\hline PPAR $\gamma$ ORF4 & $\begin{array}{l}\text { CAG TGG GGA TGT CTC ATA ATG C } \\
\text { AAA CCC AAA ACA ACT TCC CG }\end{array}$ & 275 & 65 & 87 \\
\hline FABP1 & $\begin{array}{l}\text { TGA TCC AAA ACG AAT TCA CG } \\
\text { CCT TCC AAC TGA ACC ACT GTC }\end{array}$ & 88 & 63 & 78 \\
\hline B-actin & $\begin{array}{l}\text { CCT TCC TGG GCA TGG AGT CCT G } \\
\text { GGA GCA ATG ATC TTG ATC TTC }\end{array}$ & 202 & 63 & 87 \\
\hline
\end{tabular}

\section{Results}

PPAR expression in colon adenocarcinoma. We first tested the expression of PPAR $\gamma$ in a series of 28 cases of human colon adenocarcinoma at the mRNA level by real-time PCR. The oligonucleotides used were selected on exons 3 and 5, thus enabling the quantification of only the 'normal' functional PPAR $\gamma$ transcripts, and not the dominant negative variant ORF4 (Fig. 1). The PPAR $\gamma$ expression levels in the tumors were represented relative to the normal paired mucosa. PPAR $\gamma$ expression in the tumor was considered to be increased when the ratio, tumor vs normal colon, was $>1.5$ and was considered to be decreased when the ratio was $<0.5$.

As shown in Fig. 2, PPAR $\gamma$ transcript levels were highly variable among patients, ranging from 0.04 to 8.8 (median, 1.0). PPAR $\gamma$ was overexpressed in 10 out of 28 cases (35.7\%; range, 1.8-8.8; and median, 2.9). By contrast, a $50 \%$ decreased expression was seen in 9 patients $(32.1 \%)$, and no significant change was observed in 9 samples $(32.1 \%)$.

To note, PPAR $\gamma$ is expressed by colonic epithelial cells, but also by nonepithelial cells of the normal mucosa and by stromal cells surrounding the tumor (22). Therefore, in order to determine whether the difference in expression observed in whole tumors was dependent or not on the expression in epithelial cells, immunohistochemical analysis was performed on paraffin-embedded sections using an antibody directed towards the $\mathrm{C}$-terminal region of the protein. The results obtained were consistent with those described above at the mRNA level, and demonstrated that epithelial colon cancer cells can show up- or down-regulation of PPAR $\gamma$ expression at the protein level (data not shown).

ORF4 expression in colon adenocarcinoma. We next determined the expression level of the ORF4 PPAR $\gamma$ transcript in our samples by using the same sense oligonucleotide that was used for PPAR $\gamma$ (exon 3), and an antisense probe located on intron 4 (Fig. 1). Real-time amplifications were performed and the relative ORF4 levels are presented for each patient (Fig. 2). ORF4 was overexpressed in 13 out of 28 tumors (46.4\%; range, 1.7-10.8; and median, 3.9). A decreased expression was seen in 8 patients $(28.6 \%)$, and no significant change was observed in 7 samples $(25.0 \%)$. When

Ex 1 Ex 2 Ex 3 Ex 4 Ex 5 Ex 6

PPAR $\gamma$

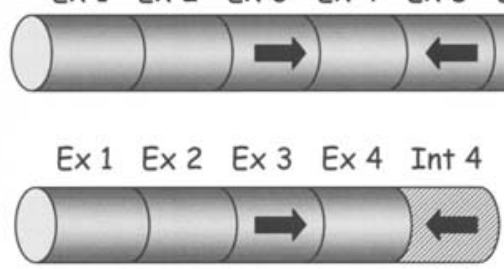

Figure 1. Schematic representation of PPAR $\gamma$ and ORF4 transcripts. The oligonucleotides used for the specific amplifications are represented by arrows.

comparing PPAR $\gamma$ and ORF4 levels, different situations were observed. The 9 tumors that expressed low levels of PPAR $\gamma$ also expressed reduced levels of ORF4. This may have been related to a general decreased transcription of the $P P A R \gamma$ gene. Six tumors $\left(\mathrm{N}^{\circ} 12,13,20,24,26\right.$ and 28) presented similar PPAR $\gamma$ and ORF4 expression levels, and 4 tumors presented a lower ORF4 expression level (14, 15, 18 and 21). Finally, and more interestingly, the remaining 9 tumors $(32.1 \%)$ presented the ORF4 variant at a much higher level than the 'normal' PPAR $\gamma$ transcript. In these cases, therefore, it is tempting to speculate that PPAR $\gamma$ ligands would not induce gene transcription, and might even stimulate cell proliferation. If this is true, then PPAR $\gamma$ ligands would not be efficient in treating colon cancer in these patients.

The dominant negative effect of ORF4 reported by Sabatino et al (17) was demonstrated in vitro. Cells were transfected with fixed amounts of a reporter gene and PPAR $\gamma$ expression vector together with increasing concentrations of ORF4 cDNA-containing vector. An 40\% decrease of the PPAR $\gamma$-induced response was obtained when the ORF4:PPAR $\gamma$ ratio was $1: 1$. The repression increased to $\sim 80 \%$ for a $5: 1$ ratio. In order to determine the relative expression level in human tissue samples, we compared PPAR $\gamma$ and ORF4 relative expression levels in both normal colonic mucosa and colon adenocarcinomas (paired samples). The results are presented in Fig. 3. Both in normal colonic mucosa and in colon adenocarcinomas, the ratio ORF4:PPAR $\gamma$ was $<0.10$, indicating that in all these samples, the ORF4 transcript 


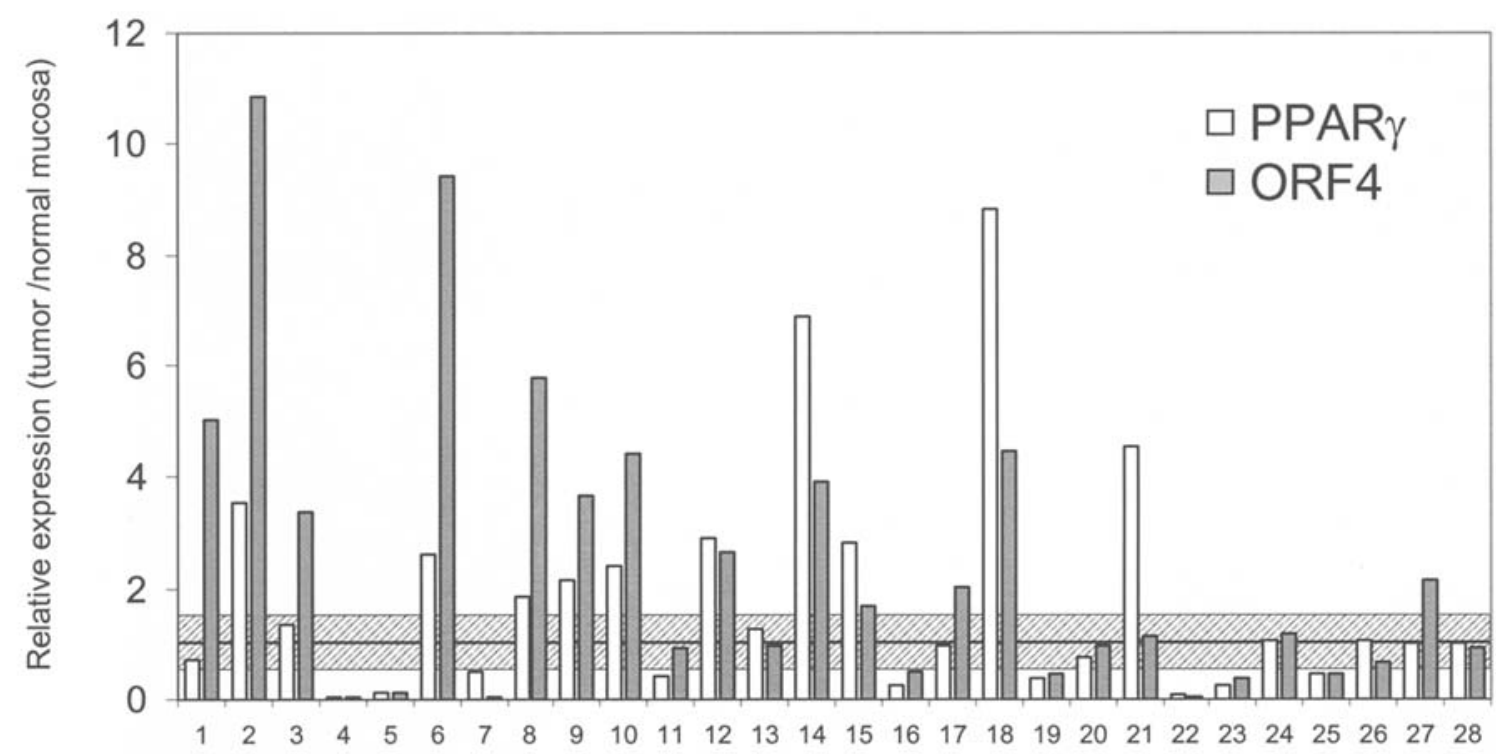

Patient $\mathrm{N}^{\circ}$

Figure 2. The PPAR $\gamma$ gene expression in colon tumors. RNAs were extracted from the different samples, converted to cDNA, and quantified by real-time PCR as detailed in Materials and methods. The results are presented as ratios between expression in the tumor and paired normal colonic mucosa. The hatched region indicates a similar expression in the tumor and the paired normal colon (ratio $>0.5$ and $<1.5$ ).

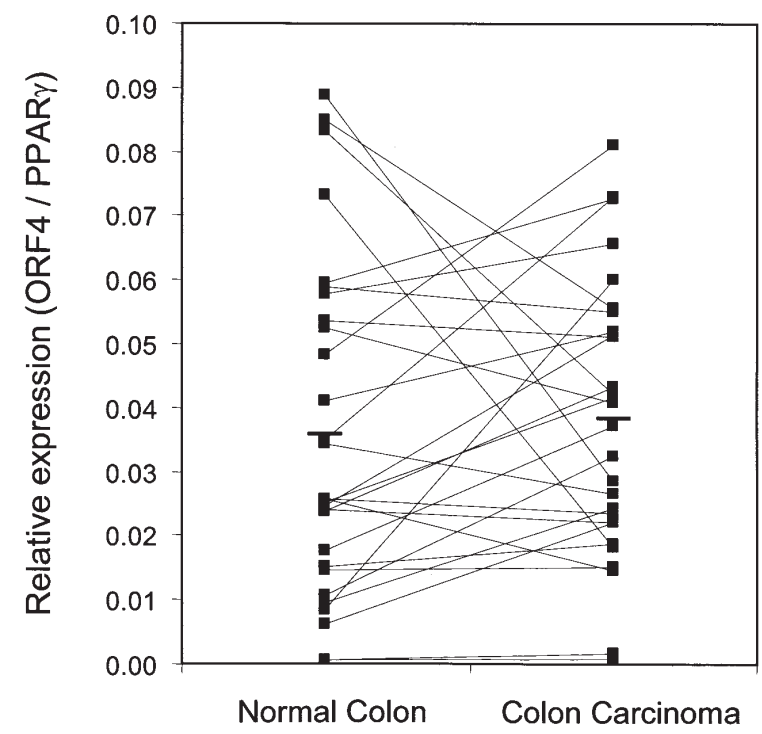

Figure 3. Relative expression of PPAR $\gamma$ and ORF4 in colon carcinomas and paired normal colonic mucosa. RNAs were extracted from the different samples, converted to cDNA, and quantified by real-time PCR as described in Materials and methods. The results are presented as ratios between expression of ORF4 and PPAR $\gamma$ in the normal mucosa and colon carcinoma. Horizontal lines represent median values.

represents $<10 \%$ of the total PPAR $\gamma$ transcripts. In such conditions, the dominant negative effect of ORF4 is probably not efficient.

Regulation of PPAR $\gamma$ and ORF4 by GW7845, a specific $P P A R \gamma$ ligand in human colon cancer cell lines. We next attempted to ascertain what would happen in the presence of a PPAR $\gamma$ ligand, e.g. during treatment. As models, we used the following human colon cancer cell lines: 3 differentiated cell lines cultured on porous filters (HT29-Cl.16E, Caco2 and T84), and 3 non-differentiated cell lines, cultured on plastic (SW116, SW620 and LS174T). These cell lines which all expressed PPAR $\gamma$ (data not shown) were treated with a synthetic PPAR $\gamma$ agonist, GW7845. As a control of induction, we measured the expression level of the FABP1 gene, a known PPAR $\gamma$ target (23). An increased FABP1 level was found in the different cell lines, although variably, ranging from 1.6-fold in Caco2 cells to 33.4-fold in HT29-Cl.16E cells (Fig. 4A). In these cell lines, a decreased expression of PPAR $\gamma$ was seen upon GW7845 treatment (data not shown). In such samples, we measured the relative ratio between ORF4 and PPAR $\gamma$ (Fig. 4B). Except for SW620 cells, the ratio ORF4: PPAR $\gamma$ was also $<10 \%$, as described for human tissue samples. Treatment with the PPAR $\gamma$ agonist did not modify this ratio (Fig. 4B).

PPAR $\gamma$ and ORF4 expression in isolated human colonic epithelial cells. As mentioned above, PPAR $\gamma$ expression is not restricted to epithelial cells in the colon. Therefore, we next determined the expression level of PPAR $\gamma$ and ORF4 in epithelial cells isolated from normal colonic mucosa taken at a distance from the carcinoma. The data are presented in Fig. 5. In agreement with what we observed using whole colonic mucosa as samples, the relative ORF4/PPAR $\gamma$ expression level ranged between only 5 and $15 \%$ (Fig. 5C).

We also analyzed epithelial cells from the inflamed colonic mucosa from patients with ulcerative colitis, a chronic inflammatory bowel disease which presents an increased risk of colorectal cancer. As previously reported (24), there was a decreased expression of PPAR $\gamma$ in epithelial cells isolated from ulcerative colitis compared with those from the normal colon (Fig. 5A). ORF4 expression was also decreased in 

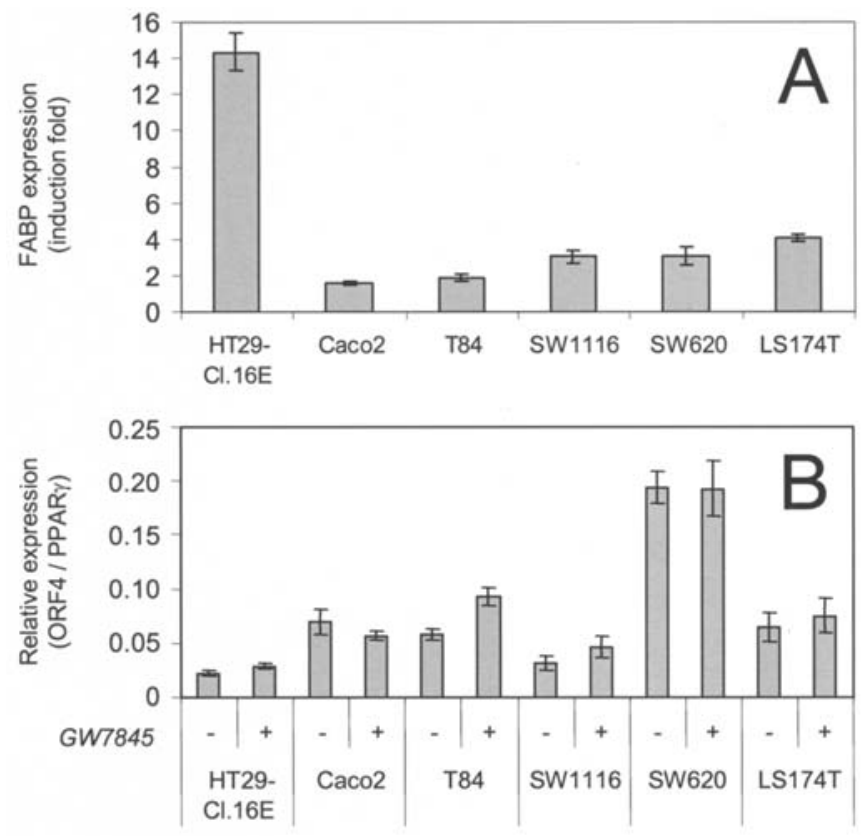

Figure 4. Regulation of PPAR $\gamma$ and ORF4 mRNA levels by PPAR $\gamma$ agonist treatment of colon cancer cell lines. RNA was extracted from post-confluent cells, treated or not with GW7845, and real-time PCR was performed as described in Materials and methods. FABP levels, expressed as induction fold in the presence of GW7845 (compared with the absence of GW7845), served as a control of induction by GW7845 (A). The ratios between expression of ORF4 and PPAR $\gamma$ were determined in these cell cultures in the absence (-) and in the presence (+) of GW7845 (B).

these samples as compared to normal colonocytes (Fig. 5B). Furthermore, the relative ORF4/PPAR $\gamma$ expression level remained largely unchanged in cells from ulcerative colitis suggesting a parallel regulation of both transcripts in inflammatory conditions.

\section{Discussion}

Here we characterized the relative expression of PPAR $\gamma$ and ORF4 in human colorectal adenocarcinoma. First, we demonstrated a heterogeneous PPAR $\gamma$ expression level between tumors. Such a heterogeneity was also reported by Feilchenfeldt et al (25). However their use of oligonucleotides spanning exons 1 and 2 did not allow them to distinguish PPAR $\gamma$ expression from that of the ORF4 splicing variant.

The human PPAR $\gamma$ gene has been isolated, and nine exons were first identified (26). Due to different promoter usage (27-29) and alternative splicing, the human PPAR $\gamma$ gene generates 3 main PPAR $\gamma$ mRNAs: PPAR $\gamma 1$, PPAR $\gamma 2$, and PPAR $\gamma 3$ (26,29). These transcripts show differential tissue distribution in the human (26,29-31). PPAR $\gamma 1$ and $\gamma 3$ give rise to the same protein (PPAR $\gamma 1)$. PPAR $\gamma 2$ expression is confined to adipose tissue and its protein has 28 additional amino acids at the $\mathrm{N}$-terminus $(26,32)$. In co-transfection assays, these two isoforms were activated to the same extent by PPAR $\gamma$ ligands $(30,33)$. Additional transcripts have been identified in monkey macrophages (34) and in human THP1 macrophages (35).

The recently described ORF4 variant harbors a readthrough in intron 4 . The expected protein exhibits impaired
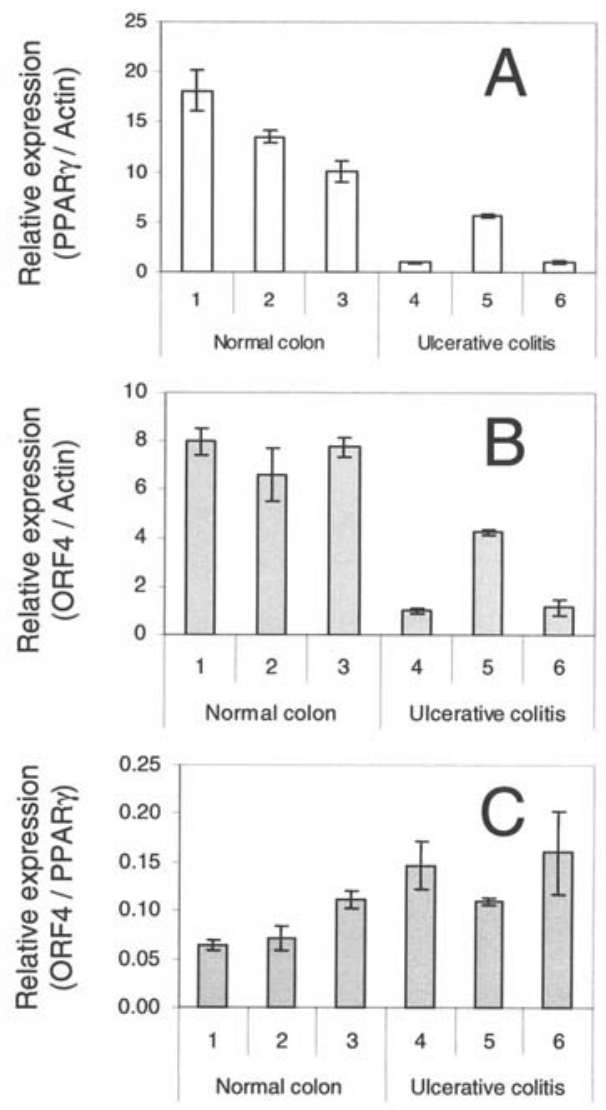

Figure 5. Relative expression of ORF4 and PPAR $\gamma$ in preparations of epithelial cells isolated from human normal colon, and inflamed mucosa from ulcerative colitis patients. RNAs were extracted from the different samples, converted to cDNA, and quantified by real-time PCR as described in Materials and methods. For each patient, the PPAR $\gamma$ and the ORF4 expression levels are presented.

transactivation activity and stimulates growth of transfected cells. Furthermore, it acts as a dominant negative regulator of the wild-type PPAR $\gamma$ isoform. It was thus of interest to determine its expression level in colon tumors and to compare it to the 'normal' PPAR $\gamma$ level. We found no correlation between ORF4 overexpression and tumor location, stage or differentiation in this series of colon cancer patients. Notably, in the overwhelming majority of the tested samples, ORF4 was found to represent $<10 \%$ of PPAR $\gamma$ transcripts.

These quantifications were conducted at the mRNA level, but it was tempting to speculate that such a difference was also present at the protein level. We have raised polyclonal antibodies against ORF4. Unfortunately, we have not been able to detect the ORF4 protein in Western blot experiments. This might have been due to the low level of ORF4 protein present in our protein extracts.

ORF4 expression was very similar between colon cancer cell lines and human colon carcinomas. As mentioned above, PPAR $\gamma$ ligands inhibited the growth of colon cancer cells in xenograft models (5-7). This supports the hypothesis that the low ORF4 expression level should not affect the efficiency of selective PPAR $\gamma$ modulators in colon cancer treatment in humans.

All the human samples used in this study were collected from patients. Although histologically 'normal' samples were collected at a distance from the tumors, we cannot exclude an 
altered expression of ORF4 in these samples. As it is ethically impossible to obtain normal human asymptomatic colon cells in a sufficient amount to isolate epithelial cells, we isolated RNA from normal mouse colon, synthesized cDNA, and quantified PPAR $\gamma$ and ORF4 relative levels by real-time PCR. This analysis allowed us to demonstrate that the ORF4 transcript is also present in mouse colon, and that it also accounts for $<10 \%$ of the PPAR $\gamma$ transcripts in these normal cells (data not shown). We thus concluded that the ORF4 splicing variant is present in normal colonic cells. Furthermore, the ratio ORF4:PPAR $\gamma$ is relatively constant in normal colon, colon adenocarcinoma and inflammatory bowel disease, indicating a parallel regulation of PPAR $\gamma$ and ORF4 expression in these different situations.

Alternative splicing is a commonly used mechanism and $30-60 \%$ of human genes are thought to undergo this regulatory mechanism that results in protein diversity (36). It is implicated in many normal biological processes, and has been associated with pathologies including human genetic diseases (37) and cancer (38). Nuclear receptors have been involved in this context. For instance, an altered androgen receptor presenting an in-frame alternative splice lacking exon 3, which removes 36 amino acids in-frame from the DNA-binding domain, was detected in all of the 8 breast tumors but not in any of the 5 normal samples (39).

The most common forms of splicing defects are genomic splice site point mutations. For instance, a recent survey found 29 different p53 splice site mutations in different types of cancer (40). Exons are usually flanked by the intronic dinucleotides GT and AG at the 5' and 3' splice sites respectively, and mutation of these sites usually causes exclusion of the adjacent exon. In the case of ORF4, intron 4 is not eliminated during the process. Sabatino et al (17) found no mutation in the exon-intron junctions that could explain the readthrough in intron 4.

In conclusion, the PPAR $\gamma$ signaling pathway can be affected in human colon adenocarcinoma by rare loss-offunction mutations of the PPAR $\gamma$ gene, decreased expression, and variations in the ratio of different isoforms generated by alternative splicing. The ORF4 expression level is too low to antagonize the cellular function of the wild-type PPAR $\gamma$, but additional splicing variants with dominant negative activity might exist. New therapeutic approaches targeting the PPAR $\gamma$ receptor should take into account all these factors, but also the expression of PPAR $\gamma$ partners (co-activators and co-repressors). Such a complete analysis may provide new insights and targets for managing, detecting, and preventing colon cancer.

\section{Acknowledgements}

This study was supported by grants from the Ligue Départementale contre le Cancer (44 and 56), from the Association pour la recherche contre le Cancer (no. 3732), and from Région Bretagne (ACOMB 2627).

\section{References}

1. Lefebvre AM, Chen I, Desreumaux P, et al: Activation of the peroxisome proliferator-activated receptor gamma promotes the development of colon tumors in C57BL/6J-APCMin/+ mice. Nat Med 4: 1053-1057, 1998.
2. Saez E, Tontonoz P, Nelson MC, et al: Activators of the nuclear receptor PPARgamma enhance colon polyp formation. Nat Med 4: 1058-1061, 1998.

3. Koeffler HP: Peroxisome proliferator-activated receptor gamma and cancers. Clin Cancer Res 9: 1-9, 2003.

4. Michalik L, Desvergne B and Wahli W: Peroxisome-proliferatoractivated receptors and cancers: complex stories. Nat Rev Cancer 4: 61-70, 2004.

5. Yoshizumi T, Ohta T, Ninomiya I, et al: Thiazolidinedione, a peroxisome proliferator-activated receptor- $\gamma$ ligand, inhibits growth and metastasis of HT-29 human colon cancer cells through differentiation-promoting effects. Int J Oncol 25: 631-639, 2004.

6. Sarraf P, Mueller E, Jones D, et al: Differentiation and reversal of malignant changes in colon cancer through PPARgamma. Nat Med 4: 1046-1052, 1998.

7. Kitamura S, Miyazaki Y, Shinomura Y, Kondo S, Kanayama S and Matsuzawa Y: Peroxisome proliferator-activated receptor gamma induces growth arrest and differentiation markers of human colon cancer cells. Jpn J Cancer Res 90: 75-80, 1999.

8. Gupta RA, Brockman JA, Sarraf P, Willson TM and Dubois RN: Target genes of peroxisome proliferator-activated receptor gamma in colorectal cancer cells. J Biol Chem 276: 29681-29687, 2001.

9. Osawa E, Nakajima A, Wada K, et al: Peroxisome proliferatoractivated receptor gamma ligands suppress colon carcinogenesis induced by azoxymethane in mice. Gastroenterology 124: 361-367, 2003.

10. Tanaka T, Kohno H, Yoshitani S, et al: Ligands for peroxisome proliferator-activated receptors alpha and gamma inhibit chemically induced colitis and formation of aberrant crypt foci in rats. Cancer Res 61: 2424-2428, 2001.

11. Kohno H, Yoshitani S, Takashima S, et al: Troglitazone, a ligand for peroxisome proliferator-activated receptor gamma, inhibits chemically-induced aberrant crypt foci in rats. Jpn $J$ Cancer Res 92: 396-403, 2001.

12. Girnun GD, Smith WM, Drori S, et al: APC-dependent suppression of colon carcinogenesis by PPARgamma. Proc Natl Acad Sci USA 99: 13771-13776, 2002.

13. Sarraf P, Mueller E, Smith WM, et al: Loss-of-function mutations in PPAR gamma associated with human colon cancer. Mol Cell 3: 799-804, 1999.

14. Ikezoe T, Miller CW, Kawano S, et al: Mutational analysis of the peroxisome proliferator-activated receptor gamma gene in human malignancies. Cancer Res 61: 5307-5310,2001.

15. Gupta RA, Sarraf P, Mueller E, et al: Peroxisome proliferatoractivated receptor gamma-mediated differentiation: a mutation in colon cancer cells reveals divergent and cell type-specific mechanisms. J Biol Chem 278: 22669-22677, 2003.

16. Bouancheau D, Buecher B, Jarry A, et al: The PPAR(gamma) K422Q mutation does not contribute to troglitazone inefficiency in colon cancer treatment. Cancer Lett 224: 111-116, 2005.

17. Sabatino L, Casamassimi A, Peluso G, et al: A novel peroxisome proliferator-activated receptor gamma isoform with dominant negative activity generated by alternative splicing. J Biol Chem 280: 26517-26525, 2005.

18. Branka JE, Vallette G, Jarry A, et al: Early functional effects of Clostridium difficile toxin A on human colonocytes. Gastroenterology 112: 1887-1894, 1997.

19. Augeron C and Laboisse CL: Emergence of permanently differentiated cell clones in a human colonic cancer cell line in culture after treatment with sodium butyrate. Cancer Res 44: 3961-3969, 1984.

20. Suh N, Wang Y, Williams CR, et al: A new ligand for the peroxisome proliferator-activated receptor-gamma (PPARgamma), GW7845, inhibits rat mammary carcinogenesis. Cancer Res 59: 5671-5673, 1999.

21. Blanchot-Jossic F, Jarry A, Masson D, et al: Up-regulated expression of ADAM17 in human colon carcinoma: coexpression with EGFR in neoplastic and endothelial cells. J Pathol 207: 156-163, 2005.

22. Lefebvre M, Paulweber B, Fajas L, et al: Peroxisome proliferatoractivated receptor gamma is induced during differentiation of colon epithelium cells. J Endocrinol 162: 331-340, 1999.

23. Perera RJ, Marcusson EG, Koo S, et al: Identification of novel PPARgamma target genes in primary human adipocytes. Gene 369: 90-99, 2006.

24. Dubuquoy L, Jansson EA, Deeb S, et al: Impaired expression of peroxisome proliferator-activated receptor gamma in ulcerative colitis. Gastroenterology 124: 1265-1276, 2003. 
25. Feilchenfeldt J, Brundler MA, Soravia C, Totsch M and Meier CA: Peroxisome proliferator-activated receptors (PPARs) and associated transcription factors in colon cancer: reduced expression of PPARgamma-coactivator 1 (PGC-1). Cancer Lett 203: 25-33, 2004.

26. Fajas L, Auboeuf D, Raspe E, et al: The organization, promoter analysis, and expression of the human PPARgamma gene. J Biol Chem 272: 18779-18789, 1997.

27. Sundvold H and Lien S: Identification of a novel peroxisome proliferator-activated receptor (PPAR) gamma promoter in man and transactivation by the nuclear receptor RORalpha1. Biochem Biophys Res Commun 287: 383-390, 2001.

28. Wang X, Southard RC and Kilgore MW: The increased expression of peroxisome proliferator-activated receptorgamma1 in human breast cancer is mediated by selective promoter usage. Cancer Res 64: 5592-5596, 2004.

29. Fajas L, Fruchart JC and Auwerx J: PPARgamma3 mRNA: a distinct PPARgamma mRNA subtype transcribed from an independent promoter. FEBS Lett 438: 55-60, 1998.

30. Mukherjee R, Jow L, Croston GE and Paterniti JR Jr: Identification, characterization, and tissue distribution of human peroxisome proliferator-activated receptor (PPAR) isoforms PPARgamma2 versus PPARgamma1 and activation with retinoid X receptor agonists and antagonists. J Biol Chem 272: 8071-8076, 1997

31. Ricote M, Huang J, Fajas L, et al: Expression of the peroxisome proliferator-activated receptor gamma (PPARgamma) in human atherosclerosis and regulation in macrophages by colony stimulating factors and oxidized low density lipoprotein. Proc Natl Acad Sci USA 95: 7614-7619, 1998.
32. Knouff C and Auwerx J: Peroxisome proliferator-activated receptor-gamma calls for activation in moderation: lessons from genetics and pharmacology. Endocr Rev 25: 899-918, 2004.

33. Elbrecht A, Chen Y, Cullinan CA, et al: Molecular cloning, expression and characterization of human peroxisome proliferator activated receptors gamma 1 and gamma 2. Biochem Biophys Res Commun 224: 431-437, 1996.

34. Zhou J, Wilson KM and Medh JD: Genetic analysis of four novel peroxisome proliferator activated receptor-gamma splice variants in monkey macrophages. Biochem Biophys Res Commun 293: 274-283, 2002.

35. Chen Y, Jimenez AR and Medh JD: Identification and regulation of novel PPAR-gamma splice variants in human THP-1 macrophages. Biochim Biophys Acta 1759: 32-43, 2006.

36. Maniatis T and Tasic B: Alternative pre-mRNA splicing and proteome expansion in metazoans. Nature 418: 236-243, 2002.

37. Cartegni L, Chew SL and Krainer AR: Listening to silence and understanding nonsense: exonic mutations that affect splicing. Nat Rev Genet 3: 285-298, 2002.

38. Venables JP: Aberrant and alternative splicing in cancer. Cancer Res 64: 7647-7654, 2004.

39. Zhu X, Daffada AA, Chan CM and Dowsett M: Identification of an exon 3 deletion splice variant androgen receptor mRNA in human breast cancer. Int J Cancer 72: 574-580, 1997.

40. Holmila R, Fouquet C, Cadranel J, Zalcman G and Soussi T: Splice mutations in the p53 gene: case report and review of the literature. Hum Mutat 21: 101-102, 2003. 